Article

\title{
External Thermal Insulation Composite Systems (ETICS) from Industry and Academia Perspective
}

\author{
Jacek Michalak (iD
}

check for updates

Citation: Michalak, J. External Thermal Insulation Composite Systems (ETICS) from Industry and Academia Perspective. Sustainability 2021, 13, 13705. https://doi.org/ $10.3390 /$ su132413705

Academic Editors: Marc A. Rosen and Luisa F. Cabeza

Received: 19 October 2021

Accepted: 8 December 2021

Published: 11 December 2021

Publisher's Note: MDPI stays neutral with regard to jurisdictional claims in published maps and institutional affiliations.

Copyright: (C) 2021 by the author. Licensee MDPI, Basel, Switzerland. This article is an open access article distributed under the terms and conditions of the Creative Commons Attribution (CC BY) license (https:/ / creativecommons.org/licenses/by/ $4.0 /)$.
Research and Development Center, Atlas sp. z o.o., 2, Kilinskiego St., 91-421 Lodz, Poland; jmichalak@atlas.com.pl

\begin{abstract}
External Thermal Insulation Composite System (ETICS) is a commonly used solution in EU countries to increase building energy efficiency. The article describes ETICS in terms of environmental impact from two perspectives, i.e., industry and academia. In EU countries, ETICS manufacturers to place construction products to the market must subject it to the assessment and verification of constancy of performance (AVCP). The basis of this process is the European Technical Assessment (ETA). Based on the number of issued and valid ETAs for ETICS and the number of Environmental Product Declarations (EPDs), the dimension of sustainability issues was discussed. Analysis of one of the environmental indicators (Global Warming Potential-GWP) for ETICS with EPS, XPS, and MW showed only a general trend. However, there are significant differences between the values of the GWP and other environmental indicators that one can use for future AVCP of construction products. In the light of the research described in the paper, it seems reasonable to conclude that AVCP for ETICS in terms of sustainability will be challenging to implement in practice-based only on environmental indicators according to EN 15804. The article also reviews scientific publications on the sustainability of ETICS.
\end{abstract}

Keywords: External Thermal Insulation Composite System (ETICS); Environmental Product Declaration (EPD); European Technical Assessment (ETA); sustainability; assessment and verification of constancy of performance (AVCP); Global Warming Potential (GWP)

\section{Introduction}

The absolute reduction in the consumption of fossil fuels and the increase in energy efficiency is the necessity of an effective transformation to a zero-carbon global economy, which will allow us to stop and ultimately mitigate climate changes that threaten our civilization. A circular economy, resources, affordability, and energy efficiency, decarbonizing the economy are priority issues for future sustainable development in the EU [1]. The European Commission, recognizing the importance of the problem in its ambitious European Green Deal strategy, decided to make Europe the world leader in the circular economy and the first climate-neutral continent [2]. Additionally, to help Member States recover from the crisis following the COVID-19 pandemic to the Multiannual Financial Framework (MFF) for 2021-2027, the EU added the recovery plan (NextGenerationEU). The EU constructed the MFF and NextGenerationEU in order not only to rebuild the EU economy but also to drive the green transformation. EUR 373.9 billion has been allocated to natural and environmental resources, including EUR 356.4 billion under the MFF [3].

In 1957, the world's first external thermal insulation composite system (ETICS) was installed on a residential building in Berlin. Following the Germans, this solution was introduced by the Swiss and the Austrians. The beginning of the 1970s was a breakthrough in gaining European markets for ETICS when many countries were shaken by the first fuel crisis of such magnitude. The resulting increase in energy prices became an impulse to reflect on the need to minimize heat losses in the building - the development of the industry accelerated, and the awareness of the benefits of external insulating walls was growing [4]. 
Another critical stage in the development of ETICS in Europe was the admission of new member states from Central and Eastern Europe to the EU. Until the end of the 1990s, the construction of prefabricated residential housing was standard in these countries, the number of buildings requiring insulation was enormous [5]. From the beginning of this century, the EU, implementing the provisions of the Kyoto Protocol and the EU's policy, defined increased energy efficiency as a strategic goal. The expression of EU activities in this area was the adoption of three key directives that cover the reduction and optimization of energy consumption in building over the past twenty years, followed by the adoption in 2002 of Directive 2002/91/EC [6], and in 2010 of Directives 2010/31/EU [7] and 2018/844 [8]. All this and the fact that the years of using ETICS have proven in practice their durability and long-term performance [9] resulted in the development of ETICS, making this method the most widely used method today in the EU [4]. It was and is not without significance in the success of the ETICS that the installation itself is relatively quick and does not require the use of too complicated methods. ETICS is used to insulate both new and renovated buildings. In 2017, more than 234 million square meters of external walls of buildings were insulated using ETICS [10]. According to the latest data of the European Association for ETICS, in 2020, 332.0 million square meters of external walls with an average insulation thickness of $125 \mathrm{~mm}$ were insulated in Europe [11]. On the European market, ETICS are offered by big international companies and many small and medium-sized enterprises.

In this paper, the author attempts to assess the requirements for the sustainable use of natural resources while evaluating ETICS. It is essential to know where construction products are in this respect, especially considering that the sustainability requirement is still voluntary. Additionally, only some of the elements necessary for its full implementation are available nowadays. This paper aims to determine the current state of knowledge in the field of the environmental impact of ETICS from two perspectives-industry and academia. Cross-sector cooperation is increasingly the key to both scientific and industrial success. At the same time, the intersection between theorists and practitioners is often not accessible due to several factors.

\section{Materials and Methods}

The qualitative analysis covers the documents regulating the assessment and verification of the constancy of performance (AVCP) of ETICS, based on which the manufacturer may, following the Construction Products Regulation (CPR), place the CE marking on a construction product, i.e., ETICS [12]. Based on the publicly available valid documents, European Technical Assessments (ETA), and Environmental Product Declarations (EPD), quantitative and qualitative analysis were made. Furthermore, to determine the perception of ETICS, in terms of environmental impact, a literature review was carried out using the publication database in Google Scholar. Eighteen articles were shortlisted and investigated. The author's qualitative and quantitative analysis of the environmental impact of ETICS carried out, taking into account more than twenty-five years of his professional experience with ETICS.

The discussion of the results includes suggestions on the necessary actions that should be taken to move from the phase of considering the environmental impact of ETICS at a high level of generality to a specific clearly and unambiguously defined at the European level.

\section{Results and Discussion}

Despite over sixty years of ETICS use, it has been considered an innovative productso far, no harmonized European standard (hEN) specifying requirements has been published. The result of many years of work by CEN/TC 88/WG 18 "External Thermal Insulation Composite Systems" is the publication of 11 European standards so far [13]. Announced for a long time publication of the European standard EN 17237 "Thermal insulation products for buildings-External thermal insulation composite kits with renders (ETIC kits)—Specification" has not taken place yet. Work on EN 17237 is still ongoing, the 
document is still under drafting, and possible citation in OJEU is still expected [14]. ETICS is a construction product subject to individual and product-related assessment. As a result, the manufacturer at the European level obtains an ETA. ETA provides the procedure for assessing the essential performance characteristics of a construction product permitting CE marking, which allows free movement of the construction product in the European Economic Area and Switzerland and Turkey [12]. One more critical point worth pointing out, namely when considering ETICS, that one should remember is that the construction products have specific characteristics that are strictly regulated and are primarily different from other sectors.

ETICS, like any innovative solution, should be considered in different categories. It can be the relation between academia (basic research in universities and research institutes) and industry (related to applied research, which is a consequence of basic research). When considering innovation, one could ask, "is science for industry or industry for science" [15]. However, for ETICS, it is appropriate to write: industry and science. It needs to be emphasized that the industry built the ETICS market, and academia was and is only a supplement.

\subsection{ETICS from Industry Perspective}

Knowledge from different sources should be taken into account in the design of any product [16]. Producers use knowledge from both internal and external sources to create their solutions. In creating ETICS, knowledge in-house is dominant, including the information that manufacturers obtain from customers, which is a fundamental source of innovation in many aspects.

Despite the widespread and year-by-year growing use of ETICS in many European countries in the sixties, seventies, and eighties, the first document aimed at unifying the requirements for ETICS at the European level has been published over thirty years since the first application of the solution. In 1988, the European Union for technical approval (UEAtc) issued the Directive for the Assessment of External Insulation Systems for Walls (Expanded Polystyrene Insulation Faced with a Thin Rendering), and four years later, in 1992, the Directive for the Assessment of External Wall Insulation Systems Faced with Mineral Render [17]. The above-mentioned UEAtc documents were used in the development of another essential standardization document for ETICS, i.e., published in 2000 by the European Association for Technical Approvals Guideline for European Technical Approval of External Thermal Insulation Systems (ETICS) with Rendering ETAG 004 [17]. The requirements specified in ETAG 004 were the basis for issuing European Technical Approvals until 1 July 2013, and after this date, the CPR rules came into forceEuropean Technical Assessments [12,18]. From 29 October 2020, the requirements specified in the European Assessment Document EAD 040083-00-0404 External Thermal Insulation Composite Systems (ETICS) with Renderings are the basis for the assessment of the ETICS while obtaining the ETA $[19,20]$. In principle, the ETA provides manufacturers with CE marking for construction products that are not or not fully covered by harmonized European standards (hENs) [12]. Finally, one more fundamental issue: the very definition of ETICS. ETICS is the set of components defined by the manufacturer in ETA, specified by one base coat, one type of thermal insulation product (for example, MW lamella, MW board, and EPS are examples for different thermal insulation types) [19]. Moreover, previous documents on which the evaluation of ETICS was based have identically defined this construction product [17].

Table 1 shows the search results of the valid (on 30 June 2021) ETAs for ETICS issued by all Technical Assessment Bodies (TABs) across Europe listed on the European Organization for Technical Assessment website. 
Table 1. Numbers of valid (on 30 June 2021) European Technical Assessments (ETAs) issued for ETICS elaborated based on ETAG 004 or EAD 040083-00-0404 by a member country and Technical Assessment Body (TAB) [21]. The numbers of ETAs for ETICS issued under EAD 040083-00-0404 are given in brackets.

\begin{tabular}{|c|c|c|}
\hline Member Country & TAB $^{\mathrm{a}}$ & No. of Issued ETAs \\
\hline Austria & OIB & $70(1)$ \\
\hline Belgium & UBATc & 8 \\
\hline Czech Republic & $\begin{array}{l}\text { TZUS } \\
\text { CSI }\end{array}$ & $\begin{array}{c}230(4) \\
0\end{array}$ \\
\hline Denmark & ETA & 0 \\
\hline Finland & Eurofins & 0 \\
\hline France & CSTB & 60 \\
\hline Germany & DIBt & 84 \\
\hline Hungary & ÉMI & 9 \\
\hline Ireland & $\begin{array}{c}\text { BRE } \\
\text { FM Approvals } \\
\text { NSAI }\end{array}$ & $\begin{array}{l}0 \\
0 \\
0\end{array}$ \\
\hline Italy & ITC-CNR & $54(4)$ \\
\hline Lithuania & SPSC & 5 \\
\hline Luxemburg & LUXIB & 0 \\
\hline Netherlands & $\begin{array}{c}\text { ERO } \\
\text { KIWA } \\
\text { SGS INTRON } \\
\text { SKG-IKOB }\end{array}$ & $\begin{array}{c}1(1) \\
0 \\
0 \\
0\end{array}$ \\
\hline Norway & SINTEF & 0 \\
\hline Poland & $\begin{array}{l}\text { ICiMB } \\
\text { IMBiGS } \\
\text { ITB }\end{array}$ & $\begin{array}{c}86(2) \\
3 \\
35\end{array}$ \\
\hline Portugal & $\begin{array}{l}\text { ITECONS } \\
\text { LNEC }\end{array}$ & $\begin{array}{c}6 \\
10\end{array}$ \\
\hline Romania & ICECON & 0 \\
\hline Slovak Republic & TSUS & 36 \\
\hline Slovenia & ZAG & 53 \\
\hline Spain & $\begin{array}{c}\text { IETcc } \\
\text { ITeC } \\
\text { TECNALIA }\end{array}$ & $\begin{array}{c}26(2) \\
5 \\
4\end{array}$ \\
\hline Sweden & RISE & 4 \\
\hline Switzerland & Empa & 0 \\
\hline Turkey & $\begin{array}{c}\text { CPC } \\
\text { ITBAK }\end{array}$ & $\begin{array}{c}1 \\
8(6)\end{array}$ \\
\hline
\end{tabular}

Note: search criteria: issuing assessment body (acronym) plus product area (PAC)—4 (Thermal insulation products, insulation kits/systems); in product area (PAC)—4 (Thermal insulation products, insulation kits/systems), 33 different EADs were valid on the day of the search (on 30 June 2021 ), and therefore, it was necessary to check each ETA found; the table does not include TABs that do not have the authorization to issue ETAs for product area (PAC)—4 (Thermal insulation products, insulation kits/systems); Cyprus and Latvia are not mentioned among the Member States as TABs in these countries are not authorized to issue ETAs for product area (PAC) - 4 (Thermal insulation products, insulation kits/systems); ${ }^{\text {a }}$ OIB-Austrian Institute of Construction Engineering; UBATc-Union Belge pour L'Agrément Technique de la Construction; TSUS-Technical and Test Institute for Construction; CSI-The Centre of Building Construction; ETA—Danmark A/S; Eurofins—Expert Services Ltd.; CSTB-Centre Scientifique et Technique du Bâtiment; DIBt—Deutsches Institut für Bautechnik; ÉMI—Quality Control Innovation; BRE—Global Assurance Ltd.—BRE Global Ireland; NSAI-National Standards Authority of Ireland; ITC-CNR-Construction Technologies Institute; SPSC—Certification Centre of Buildings Products LUXIB_Luxembourg Institute for Building and Technology, SA; ERO-Element Materials Technology Rotterdam B.V.; KIWA-Certification and Inspection; SGS INTRON-Certification; SKG-IKOB-Certification, Inspection and Testing of Building Products; SINTEF-Building and Infrastructure; ICiMB - Institute of Ceramics and Building Materials; IMBiGS-Institute of Mechanised Construction and Rock Mining; ITB-Building Research Institute; ITECONS-Institute for Research and Technological Development for Construction, Energy, Environment and Sustainability; LNEC-National Laboratory of Civil Engineering; ICECON—Research Institute for Construction Equipment and Technology; TSUS (Slovak Republic)—Building Testing and Research Institute; ZAG—Slovenian National Building and Civil Engineering Institute; IETcc-Eduardo Torroja Institute for Construction Science; ITeC-The Catalonia Institute of Construction Technology; TECNALIA-Research and Innovation; RISE- Research Institutes of Sweden; Empa-Swiss Federal Laboratory for Materials Science and Technology; CPC—Certification, Inspection and Test Services; ITBAK-Construction Technical Evaluation and Scientific Research Institute. 
It is worth noting that 798 ETAs issued for ETICS valid on 30 June 2021, are a significant number-from 1 July 2013 (the date of entry into force of the CPR regulation) to 31 December 2020, 8929 ETAs for non-standard construction products were issued by EOTA [22]. Of the valid 798 ETAs, only 20 were issued based on EAD 040083-00-0404, and 778 ETAs were based on ETAG 004-a document from the old legal order, i.e., before the CPR came into force. Please note that ETAs are valid for an indefinite period, which means that many of the ETAG 004-based ETAs will be used by ETICS manufacturers for the coming years.

Construction products not covered by a harmonized standard and for which an ETA has not been issued at the request of the manufacturer may be made available on the domestic market of one of the Member States in the national system of assessment and verification of constancy of performance of that country [12]. It means that, for ETICS, the manufacturer can obtain a national technical assessment in the country where the national system is in place. In Poland, where such a system operates, [23] TABs on the national level issued 152 national technical assessments for ETICS between January 2017 and July 2021 (ICiMB - 89, ITB-63) [24,25]. It means that only in Poland at the moment 276 documents exist based on which manufacturers can make AVCP for ETICS (124 ETAs + 152 national technical assessments). It also means there are 276 completed procedures for issuing a technical assessment and 276 performance studies of ETICS concerning the essential characteristic only in one member state $[17,19]$.

Table 2 shows the assessment of the performance of ETICS with renderings in the ETA process in relation to the essential characteristics (product characteristic) $[17,19]$. The set of tested ETICS features is the basis for its evaluation.

Table 2. The performance of ETICS with renderings concerning the essential characteristics according to the EAD 040083-000404 and product characteristic according to the ETAG $004[17,19]$.

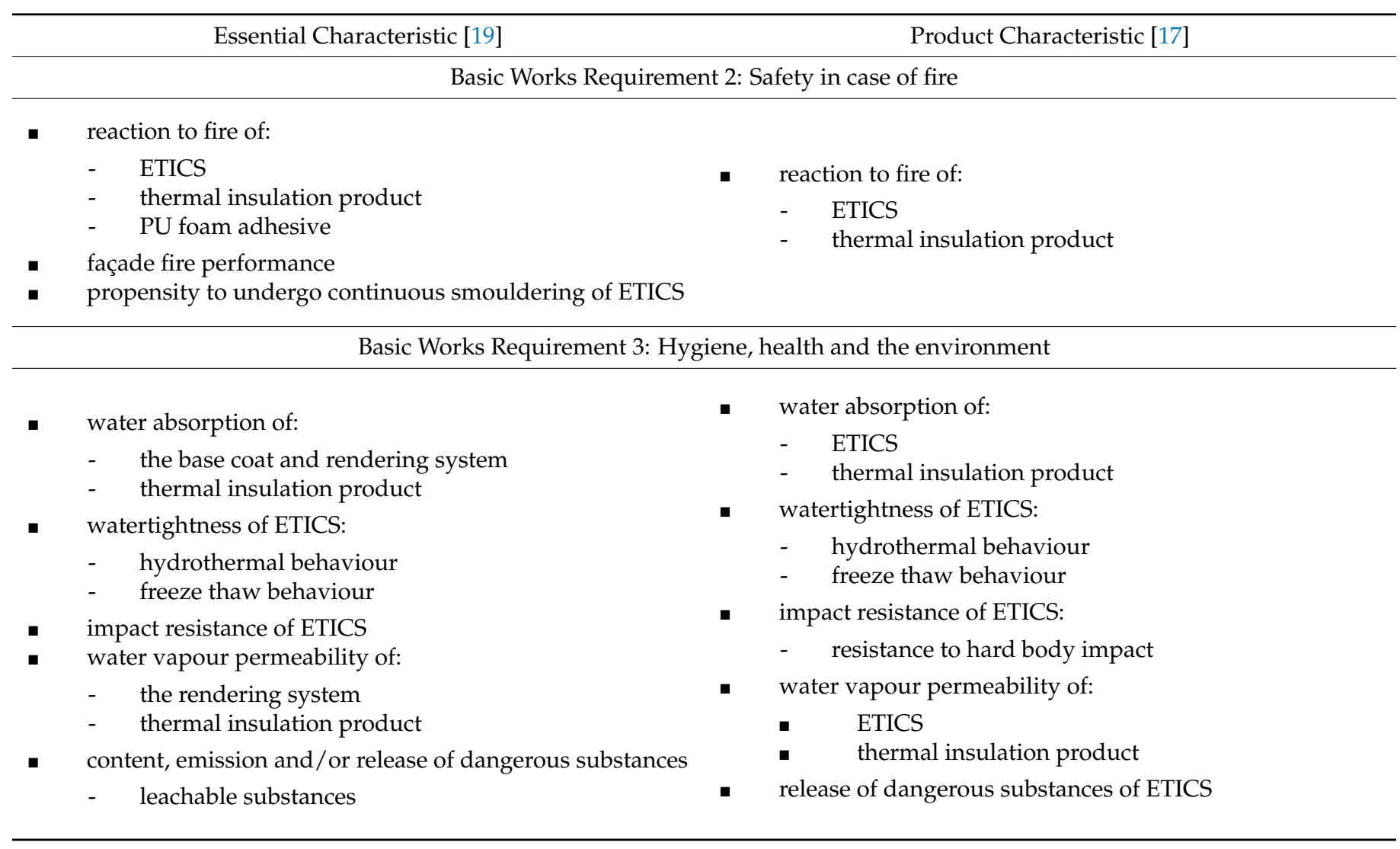


Table 2. Cont.

Basic Works Requirements 4: Safety and accessibility in use

- bond strength:

- between the base coat and the thermal insulation product (mortar or paste)

- between the adhesive and the substrate

- between the adhesive and the thermal insulation product

- $\quad$ of foam adhesives

- fixing strength:

- $\quad$ transverse displacement test

- wind load resistance of ETICS:

- pull-through tests of fixings

- $\quad$ static foam block test

- dynamic wind uplift test

- tensile test perpendicular to the faces of the thermal insulation product:

- $\quad$ in dry/wet conditions

- shear strength and shear modulus of elasticity test of ETICS

- pull-through resistance of fixings from profiles

- ender strip tensile test

- shear strength and shear modulus of foam adhesive

- post expansion behaviour of foam adhesives

- bond strength after ageing of:

- bond strength:

- between base coat and insulation product

- between adhesive and substrate

- between adhesive and insulation product

- $\quad$ of foam adhesives

- $\quad$ fixing strength (transverse displacement):

- displacement test

- $\quad$ wind load resistance of ETICS:

- pull-through tests of fixings

- $\quad$ static foam block test

- dynamic wind uplift test

- tensile test perpendicular to the faces of insulation product

- shear strength and shear modulus of elasticity test of insulation product

- pull-through resistance of fixings from profiles

- render strip tensile test

- shear strength and shear modulus of foam adhesive

- post expansion behaviour of foam adhesives

- $\quad$ finishing coat tested on the rig

- $\quad$ finishing coat not tested on the rig

- mechanical and physical characteristics of the mesh:

- $\quad$ tensile strength of the glass fibre mesh

- protection of metal mesh

Basic Works Requirements 5: Protection against noise

airborne sound insulation of ETICS

dynamic stiffness of the thermal insulation product

air flow resistance of the thermal insulation product
- $\quad$ airborne sound insulation of ETICS

- dynamic stiffness of insulation product

- air flow resistance insulation product

Basic Works Requirements 6: Energy economy and heat retention

- thermal resistance and thermal transmittance of ETICS

- thermal resistance of ETICS

- thermal resistance of insulation product

- thermal transmittance of insulation product

ETICS is not assessed concerning essential characteristics related to the BWR 1Mechanical resistance and stability and BWR 7-Sustainable use of natural resources. It should be added that requirements concerning the mechanical resistance and stability of non-load-bearing parts of the works are partially treated under BWR 4.

For BWR 7, no requirements for ETICS are defined in EAD 040083-00-0404, being the basis for the release of ETA. Sustainable use of natural resources in form of BWR 7 as defined in CPR concerning construction works has been in operation since July 1, 2013, i.e., when CPR replaced the previously applicable CPD 89/106/EEC [18]. Matters relating to BWR 7 have not changed over the last eight years due to the lack of implementation of environmental sustainability issues into European standardization resulting from the lack of a mandate for CEN from the European Commission [26].

The European Commission, recognizing the exceptional importance of issues related to the sustainability of construction materials, issued a mandate to CEN already in 2004, 
aimed at an integrated assessment of the environmental performance of buildings [27]. Eight years later, in 2012, the European standard EN 15804 for the environmental evaluation of construction products was published [28]. Recently, after several years of work, EN 15804 has been revised [29]. Environmental Product Declaration (EPD) is the most comprehensive document that gives the broadest context of the environmental impacts of a product on the environment. Type III EPDs are developed based on a product life cycle analysis (LCA) covering production, construction, use (including repair and replacement), and end of life standardized in the ISO standards: 14040 and 14044 [30,31]. In their intention, EPDs should provide transparent, reliable, quantified, and comparable information in the scope of the environmental impact of products [32,33]. However, experience so far shows that this is often not the case. EPDs issued by different organizations are developed according to the Product Category Rules (PCR) differs and attempts to compare data contained in EPDs lead to confusion [34-37]. For these reasons, harmonizing the existing EPD rules and instructions is needed to minimize/avoid potential environmental claims [38,39]. In addition, the situation is aggravated by the fact that EPDs are not mandatory but only voluntary, and thus the use of EPD's data is limited. EPDs are primarily used in several multi-criterion systems assessing building sustainability like BAMB, BREEAM, CASBEE, DGNB, Green Globes, HQE, LEED, ÖGNI, SBTool, TQB, etc. [40-42]. EPDs are also used in business-to-business (B2B) communication [43]. However, apart from green orders in some European countries, e.g., Denmark, Norway, and Sweden, EPDs have limited use.

Regardless of the path that allows the manufacturer to make an environmental assessment of the product through the development of the EPD, the European Commission initiated activities within the Single Market for Green Products Initiative by proposing the Product Environmental Footprint (PEF) method to measure environmental performance [44]. A recently published extensive study comparing EPD and PEF concluded that alternative use of both ways is impossible [45].

In January 2021, for construction products, there were globally slightly more than ten thousand verified EPDs issued by 32 EPD program operators following EN 15804 [46].

Contrary to one database containing information on issued ETAs, in the case of EPD identification, it is necessary to search the databases of each EPD program operator. This process is not the simplest for various reasons, such as: must take into account many aspects, among which the following should be considered:

- The EPD program operator defines different and limited search criteria;

- Databases in different languages;

- Sometimes no direct access to the text of the EPD.

Therefore, perhaps not all EPDs issued for the ETICS may have been identified in the study described in this work. Table 3 summarizes the essential information for EPDs developed for ETICS, which will be analyzed later in this article. In this paper, EPDs for ETICS with EPS, XPS, or MW as thermal insulation material are analyzed. Table 3 presents 15 out of 26 EPDs issued since 2016 and identified during searches in the EPD program operators databases.

Eleven EPDs were not included in Table 3 and further analysis for the following reasons:

- Concerned ETICS with natural cork boards;

- Related to ETICS with stone wool panels;

- Lack of information on the thickness of the thermal insulation material (EPS/MW);

- They were clones of EPDs issued to the producer based on the EPD issued for the association of which the producer is a member-these EPDs contained the exact data for the original EPD (mother document).

Analysis of the available EPDs released after 2016 shows that a tiny number of ETICS manufacturers have subjected their products to environmental assessment. Additionally, it is worth noting that the number of identified valid EPDs (26) issued for ETICS is negligible compared to valid ETAs (798) and technical assessments on the national level (presumably more than valid ETAs). This relation between the number of ETAs plus technical 
assessments on the national level and EPDs is not surprising. There are various reasons for this. The most important of them include, among others, the cost of developing the EPD-too high for many small and medium-sized companies, too little popularization of the document such as the EPD, and too challenging to read and interpret the values of individual environmental indicators [47]. For this reason, it is crucial to establish appropriate benchmarks that will help understand the environmental indicators given in the EPDs [48].

Table 3. Basic data on published (on 30 June 2021) EPDs for ETICS that follow the EN 15804:2012 + A1:2013 standard.

\begin{tabular}{|c|c|c|c|c|c|c|c|}
\hline No. & Program Operator & $\begin{array}{l}\text { EPD Data } \\
\text { Issued }\end{array}$ & EPD Data Year & EPD Country * & $\begin{array}{c}\text { Insulation } \\
\text { Material }\end{array}$ & Render & Ref. \\
\hline 1 & EPD International AB & 2020 & 2018 & IT & EPS & acrylic & [49] \\
\hline 2 & EPD International $\mathrm{AB}$ & 2017 & 2016 & IT & EPS/XPS/MW & acrylic & [50] \\
\hline 3 & EPD International AB & 2020 & $2018 / 2019$ & IN & EPS/XPS/MW & acrylic & [51] \\
\hline 4 & Global EPD & 2018 & 2016 & ES & MW & $\operatorname{mix}$ & [52] \\
\hline 5 & Global EPD & 2018 & 2017 & ES & EPS & $\operatorname{mix}$ & [53] \\
\hline 6 & IBU & 2017 & 2016 & $\mathrm{DE}$ & EPS & silicone & [54] \\
\hline 7 & IBU & 2017 & 2016 & $\mathrm{DE}$ & MW & silicate & [55] \\
\hline 8 & IBU & 2017 & 2016 & $\mathrm{DE}$ & MW & mineral & [56] \\
\hline 9 & IBU & 2017 & 2016 & $\mathrm{DE}$ & EPS & silicone & [57] \\
\hline 10 & ITB & 2016 & 2015 & $\mathrm{PL} / \mathrm{EE} / \mathrm{BG} / \mathrm{RS} / \mathrm{RO}$ & XPS & acrylic & [58] \\
\hline 11 & ITB & 2016 & 2015 & $\mathrm{PL} / \mathrm{EE} / \mathrm{BG} / \mathrm{RS} / \mathrm{RO}$ & MW & acrylic & [59] \\
\hline 12 & ITB & 2016 & 2015 & $\mathrm{PL} / \mathrm{EE} / \mathrm{BG} / \mathrm{RS} / \mathrm{RO}$ & EPS & acrylic & {$[60]$} \\
\hline 13 & ITB & 2019 & 2017 & PL & EPS & mineral & [61] \\
\hline 14 & ITB & 2019 & 2017 & PL & MW & mineral & [62] \\
\hline 15 & ITB & 2021 & 2018 & BG & EPS & acrylic & [63] \\
\hline
\end{tabular}

* two-letter country codes following ISO $3166-1$ alpha 2.

Figure 1 shows the Global Warming Potential (GWP) values (modules A1-A3) for 1 square meter of ETICS (functional unit) depending on the thickness of the thermal insulation material (EPS/XPS/MW) given in the EPDs listed in Table 3. In this work, three stages are analyzed: A1-extraction of raw materials, A2 - the transportation to the factory plus storage of materials used to produce ETICS components, and A3-energy provision and production processes.

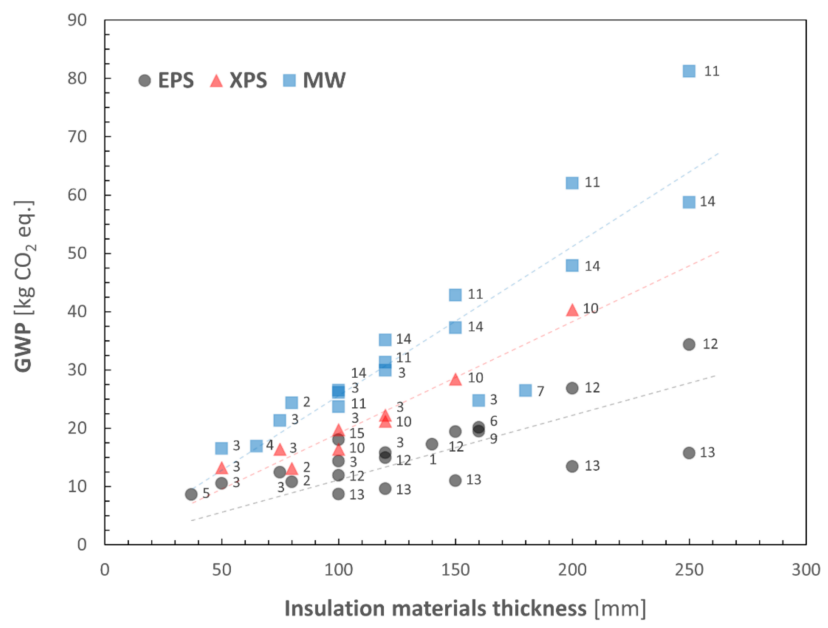

Figure 1. The GWP impact value (modules A1-A3) for 1 square meter of ETICS depends on the thickness of the thermal insulation material (EPS, XPS, MW) for the systems listed in Table 3.

The ETICS consists of several components, and the GWP value of the ETICS is the sum of the individual components. The share of thermal insulation material in the value of the GWP indicator for ETICS is significant and amounts to about $40-60 \%$ in the case of EPS [50,64-67]. In the case of XPS, it is from 50\% to 60\% [50]. For MW, it ranges from about $50 \%$ to even up to $90 \%$ depending on the thickness of the thermal insulation material [50,65-67]. The presented results in Figure 1 refer to ETICS with different rendering 
systems, which also affects the differences in the GWP index values for the ETICS. The differences between different rendering systems (acrylic, silicone, silicate, and siliconesilicate) range from a few to several percent [64]. However, although in Figure 1, the GWP indicators for ETICS are compared, not always with the same types of renders (rendering systems), the trend is visible the lowest environmental burden is related to the production (A1-A3 modules) of ETICS with EPS. The highest load for the environment is the production of ETICS with MW. This observation is in line with the GWP indicator values for EPS, XPS, and MW if they are displayed correctly, i.e., per unit area of building thermal envelope $\left(\mathrm{m}^{2}\right)$ [68]. However, what is essential from this analysis shown in Figure 1 is that the differences in GWP indicators values in many cases are so significant that they lead the reader to wonder if the values have been correctly determined.

The study of the GWP indicators values indicates a general trend. Still, it unequivocally raises the question of the validity of using environmental impact indicators for the environmental assessment of ETICS by the manufacturer. Yet, plans for using environmental impact indicators for the assessment and verification of constancy of performance (AVCP) for construction products exist [69]. Additionally, when analyzing this issue, it is worth noting that the values of the environmental impact indicators following EN 15804 are calculated based on historical production data. Verified EPDs are valid for five years, after which the manufacturer re-evaluates the product. For each manufacturer, there are many changes in production over five years, which reflect in the values of environmental indicators. Often these changes are significant, e.g., in the five years between 2012 and 2017, the GWP indicator value for ETICS with EPS with mineral renders decreased by $22 \%$ for $10 \mathrm{~cm}$ EPS, $24 \%$ for $15 \mathrm{~cm}$ EPS, and $25 \%$ for a $20 \mathrm{~cm}$ EPS [70].

In addition, another issue is the verification of the correctness of the manufacturer's assessment of environmental sustainability (BWR 7) by the market surveillance authority, which is a crucial element of the control of the EU building materials market [71,72]. An AVCP based on environmental indicators will be difficult, if not impossible, given the uncertainty issue $[34,73,74]$, which in some cases is up to $90 \%$ for GWP [74]. All these issues mentioned above clearly show the difficulty in using environmental indicators for AVCP of ETICS. Furthermore, the GWP indicator value analysis (Figure 1) results clearly show that it is impossible today to establish rational requirements for environmental indicators that could be the basis for the BWR 7 assessment for ETICS. Observation for the ETICS is in line with other tested construction products for which many more EPDs have been developed and verified, but also inconsistencies were noticed [35,74].

In this paper, only the values of GWP indicators for ETICS were analyzed (Figure 1). Nowadays, the issues of carbon neutrality, net-zero emissions, and carbon offsetting are most often analyzed. Therefore, GWP values are commonly regarded as the most reliable among environmental indicators. Other environmental indicators such as e.g., depletion potential of the stratospheric ozone layer (ODP), acidification potential of soil and water (AP), eutrophication potential (EP), formation potential of tropospheric ozone (POCP), abiotic depletion potential (ADP elements) for non-fossil resources or abiotic depletion potential (ADP fossil fuels) for fossil resources are much less popular. Data for environmental indicators other than GWP additionally often give rise to much greater confusion due to the lack of coherence between different EPDs. It is no different in a few cases for the performed EPDs analysis for ETICS specified in Table 3. For example, for ETICS with EPS with a thickness of $100 \mathrm{~mm}$, the value of the ODP index ranges from $5.11 \times 10^{-10} \mathrm{~kg}$ CFC11 eq. [51] up to $5.57 \times 10^{-5} \mathrm{~kg} \mathrm{CFC11} \mathrm{eq.} \mathrm{[60]} \mathrm{for} \mathrm{EPDs} \mathrm{listed} \mathrm{in}$ Table 3.

As mentioned earlier, only EPDs developed for ETICS with EPS, XPS, and MW were analyzed in this paper. Analyzing ETICS in terms of sustainability, it is worth noting that expanded cork agglomerate boards (ICB), a natural thermal insulation material, have a negative GWP indicator [75]. It is because, during the production, the ICB captures carbon dioxide. 
Despite that the concept of sustainable development has been present for over thirty years plus recent years of the dizzying pace of environmental degradation encourage taking quick and decisive steps to stop the negative processes for the environment, still, understanding and knowledge of sustainability issues is not common. Recent research on the understanding of the role of EPD (mandatory/voluntary) among construction market participants showed that the share of correct answers among the respondents ranges from $24.1 \%$ in the case of sellers of construction to $56.5 \%$ in the group of architects [76].

Considering BWR 7 relating to sustainable use of natural resources, it would be more reasonable to use the ETICS assessment in this aspect to define this requirement through the durability of the construction products. Such approach is in line with the content of BWR 7, which in point (b) speaks of ensuring the durability of the construction works [12]. This proposal, starting from practice, may be surprising at first. Especially considering that it is pretty common that practitioners understand the concept of the circular economy in a simple way, believing that the more materials circulated, the better it is [77]. As we know, such an understanding of circular economy does not necessarily mean greater sustainability [77]. It seems rational that after a decade of EN 15804 existence, eight years of CPR in force, and given the importance and urgency of actions in the field of sustainability, not so much has happened in the case of the environmental assessment of ETICS and other construction products, it is justified to change the approach.

Not without significance in the above considerations is the fact that ETICS improves the energy efficiency of buildings. Depending on the thickness of the insulation, the quality of its performance, the method of heating the building, and the climatic conditions outside, the energy payback period of the insulated building is no longer than two years [78].

\subsection{ETICS from Academia Perspective}

Before analyzing the issues related to the sustainability of ETICS from a scientific perspective, it is essential to recall one more important fact about ETICS. Namely: ETICS is the set of components specified by one base coat and one type of thermal insulation product $[17,19]$. Of course, in scientific research, the goal is to achieve the progress of knowledge by striving to discover so far unknown, new dependencies, by questioning what exists. A scientist who wants to achieve his goal can freely model his research. However, when examining a thermal insulation system consisting, for example, of two different thermal insulation materials, it should not be called ETICS, which is common, but rather the thermal insulation system of external walls.

The second important issue is the need to consider ETICS as a whole in testing and assessing the constancy of performance. It is evident for the producer, and this is the foundation of AVCP. Such a definition of ETICS in EAD 040083-00-0404 [19] and earlier in ETAG 004 [17] is associated with a necessary consequence: changing at least one ETICS component requires re-evaluation. From the scientific point of view, this is a limitation, which is also apparent.

The third important issue that needs to be addressed before starting the analysis of the works on sustainability and ETICS in this chapter, is that it is necessary to consider ETICS only in a holistic way from the producer's perspective. From this perspective, the statement that possible synergetic effects among different agents are often neglected by the technical documents on the evaluation of ETICS [79] is unfounded. The nature of standardization documents is, among other things, to ensure that unnecessary diversity is reduced in the production. However, it does not mean that the manufacturer does not perform multi-aspect analysis and does not perform additional tests, which, however, he does not communicate due to the requirements of AVCP and CE marking. Another dimension is the assessment of the construction product by market surveillance authorities [80]. Each responsible producer must consider his ETICS being a construction product in a comprehensive manner, remembering that in a problem situation, he will be, next to the contractor, the addressee of the customer's complaint. 
The three aspects mentioned above related to ETICS as a construction product, whose functioning on the market is regulated by CPR, are perceived differently from industry and academia. It is not that science sees them in the same way as the industry does. That is not the point. However, it is crucial to be aware of these different perspectives. It is also essential in the aspect of sustainability as science, where it is often necessary to redefine the role of the researcher [81].

The issues related to sustainability, understood as the use of environmentally friendly raw materials and secondary materials in ETICS quantified with a set of environmental indicators, are not the subject of too many publications in scientific journals. There are various reasons for this. It is probably the result of the fact that the environmental aspects of thermal insulation materials are well described in the scientific literature [68,82-85]. The thermal insulation material is an ETICS component that has a significant impact (50-90\%) on the entire system [66,67]. Therefore, determining the environmental impact of the ETICS seems to be a bit secondary issue.

Kraus et al., recognizing that ETICS is a very well-studied system in terms of technology, thermal insulation, and economics but much less known in the health and environmental aspects, performed analysis using Data Envelopment Analysis (DEA). In the seven thermal insulation materials analyses, the purchase price was an economic variable, and thermal resistance was the technical parameter. The author's survey used a questionnaire to determine the social aspect, and six environmental indicators (GWP, AP, EP, ODP, POCP, PERT) represented the environmental dimension. Out of the seven analyzed thermal insulation materials, three-EPS, blown cellulose, and wood wool—were classified by the authors as effective. The remaining four (XPS, glass wool, stone wool, and polyurethane foam) were assessed as ineffective in the analysis [86]. The successful use of the DEA method to determine the most optimal ETICS solution taking into account various positive and negative aspects has been described previously [87]. The ETICS was also subject to another assessment, which includes integrating a system in a building on a building's global performance (energy, environmental, economic, and social) by Rezai and coworkers [88]. The analysis of thermal insulation materials (rock wool, EPS, XPS, kenaf, sheep wool, cotton, recycled glass, recycled PET, and recycled textile) subjected to multi-criteria sustainability assessment using the TOPSIS method interval revealed that recycled glass and sheep wool are the most desirable options in the conducted research taking into account various scenarios [89]. At this point, however, it is worth emphasizing that the most commonly used thermal insulation material in the construction industry is EPS, whose share in the European ETICS market in 2020 was 70\%. According to the same source, MW had a $26 \%$ market share and all other thermal insulation materials only $4 \%$ [11]. It is also worth adding that in ETICS, the use of new biodegradable insulation materials, such as straw-based insulation panels with casein glue, is still being considered [90].

Potrč et al., in their research, compared the environmental impact of three systems of ETICS with the same fixed thermal transmittance parameter value of $0.27 \mathrm{~W} / \mathrm{m}^{2} \mathrm{~K}$, which corresponded to the use of EPS $14 \mathrm{~cm}$ thick, MW $12 \mathrm{~cm}$, and wood fiberboard of 16 $\mathrm{cm}$ thick. The analysis covered the following seven categories: GWP, AP, EP, ODP, POCP, ADP, and ADP fossil. The analysis results clearly showed the advantage of the ETICS with EPS for the majority of the studied categories of environmental impact. ETICS with wood fiberboard stands out in the GWP category because wood stores carbon dioxide and therefore contributes to reducing global warming [67]. Other environmental impact studies of ETICS with EPS and MW using real production data from 2017 (modules from A1 to A3) for an ETICS production corresponding to approximately 10 million square meters of insulated external walls showed that ETICS with MW has a more negative environmental impact than a system with EPS for all nine categories tested: GWP, AP, EP, ODP, POCP, ADP, ADP fossil, PERT, and PENRT [66].

Michałowski et al. studied the impact of rendering type on the environmental characteristic of ETICS with EPS. The subject of the analysis were nine environmental categories (GWP, AP, EP, ODP, POCP, ADP, ADP fossil, PERT, and PENRT) for systems with four differ- 
ent plasters (mineral, acrylic, silicone, and silicone-silicate) calculated based on production data for modules from A1 to A3. When analyzing the values of the studied indicators, it was shown that the choice of raw materials used to produce ETICS components has the most significant impact. At the same time, the share of the production process and internal transport are secondary. Systems with mineral plaster were characterized by the lowest negative impact on the environment (seven out of nine analyzed environmental categories) among the studied rendering systems [64].

Librelotto et al. analyzed the final layer of ETICS being decorative mineral render with a higher amount of lime and lower cement content. This solution is more environmentally friendly than ETICS, with mineral renders based only on cement as a binder. In addition, ETICS with cork boards (ICB) was assessed, and the use of this natural product makes ETICS even more environmentally friendly [91].

The cementitious adhesives that are part of the ETICS were also subject to environmental impact studies. The subject of the analysis was cementitious adhesives for bonding insulation material and adhesives for a base coat used in ETICS with EPS and MW systems. Comparisons were made for nine environmental categories: GWP, AP, EP, ODP, POCP, ADP, ADP fossil, PERT, and PENRT. The tested cementitious adhesives are characterized by the relatively low impact on most studied environmental categories except ODP and PERT [92].

An important aspect when considering the environmental impact is the timing of the assessment. The constant development of civilization and the related development of production technology, changes in raw materials to more environmentally friendly ones, change the environmental impact of products, including, of course, ETICS and all its components. Sustainability-oriented assessment of ETICS with EPS over a five-year period showed that changes in individual environmental indicators (GWP, AP, EP, ODP, POCP, ADP, ADP fossil, PERT, and PENRT) are significant, i.e., from several to several dozen percent [70]. It is a crucial aspect of the environmental assessment of the ETICS that must be taken into account when establishing the assessment criteria in the future.

The growing interest in environmentally friendly materials has led to the evaluation of ETICS with panels of cork insulation (ICB). The study of the global performance of systems with the ICB and EPS by Malanho et al. has shown that ETICS with ICB that reduces the environmental footprint is characterized by satisfactory global performance, similar to ETICS with EPS global performance [93]. Matos et al. presented an overview of the LCA study of ETICS with ICB developed to obtain EPD according to EN 15804 and ISO 14025 [94]. Recently, Silvestre et al. considered ETICS with EPS and ICB in the energetic renovation of the building envelope during a fifty-year study period. The use of ICB instead of EPS is beneficial in terms of environmental load for GWP and consumption of non-renewable primary energy [95].

The above-discussed environmental impact of the ETICS was related, first of all, to the environmental burden caused by the production and installation of the ETICS presented under the EPD concept resulting from EN 15804. There is another aspect of the environmental impact being the subject of the publication related to the maintenance of ETICS. It applies in particular to the aspect of possible leaching of chemical compounds derived from the biocides used, which Minarovičová emphasizes in her works [96-98]. Recognizing the importance of maintenance of ETICS, it is worth noting that damages or degradation of ETICS do not occur more often than in the case of walls covered with traditional renders. Moreover, the costs and frequency of ETICS maintenance are comparable to those external walls covered with traditional renders [9].

\section{Conclusions}

4.1. General

The analysis of the European Technical Assessments for ETICS, which were valid on the day of the analysis, showed that the Czech technical assessment body (TAB) issued the most documents—230, followed by Polish-86, German-84, and Austrian-70. It is in line 
with the estimation of the ETICS market, according to which as many as 142 million square meters of external walls have been insulated with ETICS in Central European countries [11]. TABs from four of the Scandinavian countries (Denmark, Finland, Norway, and Sweden) issued only four ETAs, which is also not surprising when you compare this number with the northern European market estimated at only 2.1 million $\mathrm{m}^{2}$ [11]. Only 20 ETAs for ETICS have been issued based on EAD 040083-00-0404, although this document is valid from the end of October 2020.

Despite that sustainable use of natural resources is the content of BWR 7 from 1 July 2013, i.e., the day when CPR requirements were applied in the EU countries, not so much has happened in this respect in the case of ETICS. In contrast to the 798 issued ETAs, the number of EPDs developed and verified by EPDs program operators is much smaller. Only 15 EPDs for ETICS with EPS, XPS, and MW identified in the EPDs program operators databases were analyzed. This insignificant number of EPDs for ETICS compared to the issued ETAs corresponds to a real interest in environmental impact issues. In some EU countries, there are national systems for placing construction products on the market in addition to the CE marking system, which also means a certain number of technical assessments for ETICS on the national level in the Member States. Of course, this is also the result that BWR 7 (sustainability) is not mandatory when the manufacturer carries out AVCP for ETICS. In addition, such a small amount of EPDs for ETICS is the result of the fact that, quite commonly, ETICS in terms of sustainability is perceived only through the prism of thermal insulation material. In the case of thermal insulation materials, the number of EPDs is much greater. For comparison, it is worth mentioning the recently published EPDs review of various insulation materials, in which Grazieschi et al. identified and analyzed as many as 156 EPDs [82].

The analysis of the GWP value for ETICS based on the 15 EPDs considered in this article shows that the general trend for each tested thermal insulation material used (EPS, XPS, and MW) in ETICS and the interrelationships between the ETICS and the three thermal insulation materials tested are identified. In many cases, the discrepancies between the GWP values for the same systems are so significant that it would not be possible to determine a threshold value of GWP for AVCP arbitrarily. The same is for the other environmental indicators. An additional argument pointing to the difficulty of using environmental indicators values for AVCP is that environmental indicators are determined based on historical data, which change over time. It is an additional aspect that prevents the effective use of environmental indicators for AVCP for ETICS. At this point, it is necessary to emphasize that EPDs are extremely useful and essential documents, and their use as a benchmark even though EPDs often vary broadly in terms of reporting results is invaluable [74]. Additionally, from the producer's perspective, knowledge of environmental impacts and their changes are crucial for the continuous improvement of production and procurement processes [99]. For these and other reasons, actions are advisable to increase the number of EPDs and thus make the databases more representative (e.g., the pre-verified EPD tool) are advisable [100].

The analysis of available EPDs in terms of one environmental indicator-GWP for the tested ETICS with EPS, XP, and MW-showed that, in the future in AVCP in the field of BWR 7, there is a need to define other requirements than those related to EPD resulting from EN 15804. It seems that it is justified to pay attention to the durability of ETICS and redefine the scope of the sustainability assessment using this feature.

The small number of scientific publications on the environmental impact of ETICS compared to the total amount of scientific papers on ETICS (more than 150) is due to various reasons. Among which should be mentioned: the identification of ETIICS when considering environmental issues only with the thermal insulation material and the fact that scientific publications mainly use data from EPDs for ETICS developed by manufacturers. 


\subsection{Featured Application from the Construction Products Industry Perspective}

This work shows the status of sustainability criterion introduction/evaluation in the AVCP process of ETICS. The requirement resulting from BWR 7 is not mandatory, and therefore not so many manufacturers evaluate their construction products regarding BWR 7 . One of the few tools to determine the environmental impact assessment of a construction product, the EPD developed following EN 15804, is used to a limited extent. The analysis of available EPDs for ETICS showed that many of the specified environmental impacts are inconsistent. In the present situation, it isn't easy to imagine that they could be the basis for establishing values of evaluation criteria. Moreover, the environmental impact indicators specified in EPDs refer to an individual system at a given time. In addition, they are determined based on historical data, and production processes and technologies undergo constant changes, which significantly affect the value of these indicators. Despite the lapse of more than eight years from the entry into force of the CPR requirements and the appearance of BWR 7, the possible implementation of a mandatory assessment in this area is not possible. Due to the importance of sustainability and the urgency of actions that should prevent unfavorable environmental changes, it seems necessary to change the approach. A possible revision of the CPR may reorganize the basic requirements and change the rules for adopting technical specifications.

In the light of the above undoubtedly crisis state of the sustainability issue in AVCP, it should be emphasized that the EPD is an important educational instrument in various dimensions. EPD is a source of knowledge for the user/customer and the manufacturer himself, which, through periodic evaluations and publication of the EPD, can monitor its activities in sustainability.

Funding: This research received no external funding.

Institutional Review Board Statement: Not applicable.

Informed Consent Statement: Not applicable.

Data Availability Statement: Not applicable.

Conflicts of Interest: The author declares no conflict of interest.

\section{References}

1. European Commission. Views on Construction. 2020 and Beyond. Brussels, Belgium. 2020. Available online: https://ec.europa. $\mathrm{eu} /$ docsroom/documents/40706 (accessed on 16 August 2021).

2. European Commission. The European Green Deal; European Commission: Brussels, Belgium, 2019.

3. European Commission. Recovery Plan for Europe; European Commission: Brussels, Belgium, 2021; Available online: https: / / ec.europa.eu/info/strategy/recovery-plan-europe_en (accessed on 16 August 2021).

4. Pasker, R. The European ETICS market-Do ETICS sufficiently contribute to meet political objectives? In Proceedings of the 4th European ETICS Forum, Warsaw, Poland, 5 October 2017; European Association for External Thermal Insulation Composite Systems (EAE): Baden-Baden, Germany, 2017.

5. Kubečková, D.; Vrbová, M. Historical Development of Thermal Protection of Prefab Residential Housing and Its Future, an Example of the Czech Republic. Energies 2021, 14, 2623. [CrossRef]

6. Directive 2002/91/EC of the European Parliament and the Council. Available online: https:/ /eur-lex.europa.eu/legal-content/ EN/ALL/?uri=CELEX:32002L0091 (accessed on 16 August 2021).

7. Directive 2010/31/EU of the European Parliament and the Council. Available online: https:/ / eur-lex.europa.eu/legal-content/ EN/TXT/?uri=CELEX:32010L0031 (accessed on 16 August 2021).

8. Directive 2018/844/EU of the European Parliament and the Council. Available online: https:/ /eur-lex.europa.eu/legal-content/ EN/TXT/?uri=CELEX:32018L0844 (accessed on 16 August 2021).

9. Künzel, H.; Künzel, H.M.; Sedlbauer, K. Long-term performance of external thermal insulation systems (ETICS). Acta Archit. 2006, 5, 11-24.

10. Instituto Pedro Nunes. Market Evaluation and Value Proposition. In Deliverable D9.2 of the HORIZON 2020 Project GELCLAD. EC Grant Agreement No. 723425; Instituto Pedro Nunes (IPN): Coimbra, Portugal, 2017; Available online: https://ec. europa.eu/research/participants/documents/downloadPublic?documentIds=080166e5b4c56d1d\&appId=PPGMS (accessed on 18 August 2021). 
11. Pasker, R. The European ETICS Market at a Glance: Facts, Figures, Latest Trends. In Proceedings of the 5th European ETICS Forum, Prague, Czech Republic, 16 September 2021; European Association for External Thermal Insulation Composite Systems (EAE): Berlin, Germany, 2021.

12. Regulation (EU). No. 305/2011 of the European Parliament and of the Council. Available online: https:/ / eur-lex.europa.eu/ legal-content/EN/TXT/?uri=CELEX:32011R0305 (accessed on 20 August 2021).

13. European Committee for Standardization (CEN). CEN Database. Available online: https://standards.cencenelec.eu/dyn/www/ $\mathrm{f} ? \mathrm{p}=205: 105: 0::::$ : searchcriteria:Committee:CEN/TC350,Standards:published (accessed on 20 August 2021).

14. European Committee for Standardization (CEN). prEN 17237:2021 Thermal Insulation Products for Buildings-External Thermal Insulation Composite Kits with Renders (ETIC Kits)-Specification; European Committee for Standardization (CEN): Brussels, Belgium, 2021.

15. Kaufmann, A.; Tödtling, F. Science-industry interaction in the process of innovation: The importance of boundary-crossing between systems. Res. Policy 2001, 30, 791-804. [CrossRef]

16. Hoarau, H.; Kline, C. Science and industry: Sharing knowledge for innovation. Ann. Tour. Res. 2014, 46, 44-61. [CrossRef]

17. European Organization for Technical Assessment (EOTA). ETAG 004: Guideline for European Technical Approval of External Thermal Insulation Composite Systems (ETICS) with Rendering; European Organization for Technical Assessment (EOTA): Brussels, Belgium, 2013.

18. The Council of European Communities. Council Directive of 21 December 1988 on the approximation of laws, regulations and administrative provisions of the Member States relating to construction products. Off. J. Eur. Union 1989, 40, $12-26$.

19. European Organization for Technical Assessment (EOTA). European Assessment Document EAD 040083-00-04040 External Thermal Insulation Composite Systems (ETICS) with Renderings; European Organization for Technical Assessment (EOTA): Brussels, Belgium, 2013.

20. European Commission. Commission Implementing Decision (EU) 2020/1574. Off. J. Eur. Union. 2020, Volume 359, p. 10. Available online: https: / / eur-lex.europa.eu/legal-content/EN/TXT/?uri=CELEX\%3A32020D1574 (accessed on 30 August 2021).

21. European Organization for Technical Assessment (EOTA). ETA Database. Available online: https://www.eota.eu/etassessments (accessed on 30 June 2021).

22. European Organization for Technical Assessment (EOTA). 2020 Annual Report, Brussels, Belgium. 2020. Available online: https:// www.eota.eu/sites/default/files/files/2021-05-18-EOTA\%20-\%20annual-report-20201805.pdf (accessed on 1 September 2021).

23. Ustawa z Dnia 16 Kwietnia 2004 Roku o Wyrobach Budowlanych, Dz.U. 2021. Available online: http:/ /isap.sejm.gov.pl/isap. nsf/download.xsp/WDU20040920881/U/D20040881Lj.pdf (accessed on 1 September 2021).

24. Łukasiewicz-Instytut Ceramiki i Materiałów Budowlanych. Wykaz Wydanych Krajowych Ocen Technicznych-13.07.2021, Cracow, Poland. Available online: http://www.icimb.pl/krakow/images/stories/pdf/jot/_Wykaz\%20wydanych\%20krajowych\% 20ocen\%20technicznych.pdf (accessed on 1 September 2021).

25. Instytut Techniki Budowlanej, ITB Database. Available online: https://biblioteka.itb.pl/F?func=find-b-0\&local_base=abud1 (accessed on 1 September 2021).

26. Wall, S. CE Marking of Construction Products-Evolution of the European Approach to Harmonisation of Construction Products in the Light of Environmental Sustainability Aspects. Sustainability 2021, 13, 6396. [CrossRef]

27. European Commission. M/350 EN Standardisation Mandate to CEN. In Development of Horizontal Standardized Methods for Assessment of the Integrated Environmental Performance of Buildings; European Commission: Brussels, Belgium, 2004.

28. European Committee for Standardization (CEN). EN 15804:2012 Sustainability of Construction Works-Environmental Product Declarations-Core Rules for the Product Category of Construction Products; European Committee for Standardization (CEN): Brussels, Belgium, 2012.

29. European Committee for Standardization (CEN). EN 15804:2012+A2:2019/AC:2021 Sustainability of Construction WorksEnvironmental Product Declarations-Core Rules for the Product Category of Construction Products; European Committee for Standardization (CEN): Brussels, Belgium, 2021.

30. International Organization for Standardization (ISO). ISO 14040:2006 Environmental Management-Life Cycle Assessment-Principles and Framework; ISO 14040:2006; International Organization for Standardization (ISO): Geneva, Switzerland, 2006.

31. International Organization for Standardization (ISO). ISO 14044:2006 Environmental Management-Life Cycle Assessment-Requirements and Guidelines; ISO 14040:2006; International Organization for Standardization (ISO): Geneva, Switzerland, 2006.

32. Brinkmann, T.; Metzger, L. Ecological assessment based on environmental product declarations. In Progess in Life Cycle Assessment; Springer: Cham, Switzerland, 2018; pp. 21-31.

33. Bovea, M.D.; Ibáñez-Forés, V.; Agustí-Juan, I. Environmental product declaration (EPD) labeling of construction and building materials. In Eco-Efficient Construction and Building Materials: Life Cycle Assessment (LCA), Eco-Labelling and Case Studies; Woodhead Publishing: New York, NY, USA, 2014; pp. 125-150. ISBN 9780857097675.

34. Waldman, B.; Huang, M.; Simonen, K. Embodied carbon in construction materials: A framework for quantifying data quality in EPDs. Build. Cities 2020, 1, 625-636. [CrossRef]

35. Anderson, J.; Moncaster, A. Embodied carbon of concrete in buildings, Part 1: Analysis of published EPD. Build. Cities 2020, 1, 198-217. [CrossRef]

36. Durão, V.; Silvestre, J.D.; Mateus, R.; De Brito, J. Economic valuation of life cycle environmental impacts of construction products-A critical analysis. IOP Conf. Ser. Earth Environ. Sci. 2019, 323, 012147. [CrossRef] 
37. Passer, A.; Lasvaux, S.; Allacker, K.; De Lathauwer, D.; Spirinckx, C.; Wittstock, B.; Kellenberger, D.; Gschösser, F.; Wall, J.; Wallbaum, H. Environmental product declarations entering the building sector: Critical reflections based on 5 to 10 years experience in different European countries. Int. J. Life Cycle Assess. 2015, 20, 1199-1212. [CrossRef]

38. Rosario, P.D.; Palumbo, E.; Traverso, M. Environmental Product Declarations as Data Source for the Environmental Assessment of Buildings in the Context of Level(s) and DGNB: How Feasible Is Their Adoption? Sustainability 2021, 13, 6143. [CrossRef]

39. Minkov, N.; Schneider, L.; Lehmann, A.; Finkbeiner, M. Type III environmental declaration programmes and harmonization of product category rules: Status quo and practical challenges. J. Clean. Prod. 2015, 94, 235-246. [CrossRef]

40. Andersen, S.C.; Larsen, H.F.; Raffnsøe, L.; Melvang, C. Environmental product declarations (EPDs) as a competitive parameter within sustainable buildings and building materials. IOP Conf. Ser. Earth Environ. Sci. 2019, 323, 012145. [CrossRef]

41. Gelowitz, M.D.C.; McArthur, J.J. Investigating the efect of environmental product declaration adoption in LEED ${ }^{\circledR}$ on the construction industry: A case study. Procedia Eng. 2016, 145, 58-65. [CrossRef]

42. Berardi, U. Sustainability assessment in the construction sector: Rating systems and rated buildings. Sustain. Dev. 2012, 20, 411-424. [CrossRef]

43. Galindro, B.M.; Welling, S.; Bey, N.; Olsen, S.I.; Soares, S.R.; Ryding, S.-O. Making use of life cycle assessment and environmental product declarations. A survey with practitioners. J. Ind. Ecol. 2020, 24, 1-11. [CrossRef]

44. European Commission. Single Market for Green Products Initiative. Available online: https://ec.europa.eu/environment/eussd/ smgp/index.htm (accessed on 12 September 2021).

45. Durão, V.; Silvestre, J.D.; Mateus, R.; de Brito, J. Assessment and communication of the environmental performance of construction products in Europe: Comparison between PEF and EN 15804 compliant EPD schemes. Resour. Conserv. Recycl. 2020, 156, 104703. [CrossRef]

46. Anderson, J. Construction LCA's 2021 Guide to Environmental Product Declarations (EPD). Available online: https: / infogram. com/constructionlcas-2021-guide-to-epd-1h1749vwlxy7l6z?live (accessed on 12 September 2021).

47. Adibi, N.; Mousavi, M. Mainstream Use of EPDs in Buildings: Lessons Learned from Europe. In Proceedings of ISBS 20194 th International Sustainable Buildings Symposium; Gültekin, A.B., Ed.; IntechOpen: Ankara, Turkey, 2019.

48. Welling, S.; Ryding, S.O. Distribution of environmental performance in life cycle assessments-Implications for environmental benchmarking. Int. J. Life Cycle Assess. 2021, 26, 275-289. [CrossRef]

49. Marcotherm. Environmental Product Declaration for Marcotherm system EPS; EPD International: Stockholm, Sweden, 2020.

50. Mapei. Environmental Product Declaration for Thermal Insulation Systems: Mapetherm EPS, Mapetherm XPS, Mapetherm M. Wool; EPD International: Stockholm, Sweden, 2017.

51. Berger. Environmental Product Declaration for Berger External Thermal Insulation \& Composite Systems (ETICS); EPD International: Stockholm, Sweden, 2020.

52. Grupo Puma, S.L. Environmental Product Declaration for Sistema Traditerm Mineral (SATE/ETICS); Global EPD: Madrid, Spain, 2018.

53. Grupo Puma, S.L. Environmental Product Declaration for Sistema de Aislamiento Térmico por el Exterior (SATE) de EPS; Global EPD: Madrid, Spain, 2018.

54. Verband für Dämmsysteme, Putz und Mörtel e.V. Environmental Product Declaration for Wärmedämm-Verbundsystem EPS mit Schienenbefestigung; IBU: Berlin, Germany, 2017.

55. Verband für Dämmsysteme, Putz und Mörtel e.V. Environmental Product Declaration for WDVS mit Mineralfaser LamellenDämmplatten Geklebt; IBU: Berlin, Germany, 2017.

56. Verband für Dämmsysteme, Putz und Mörtel e.V. Environmental Product Declaration for WDVS mit Mineralfaser Dämmplatte Geklebt und Gedübelt; IBU: Berlin, Germany, 2017.

57. Verband für Dämmsysteme, Putz und Mörtel e.V. Environmental Product Declaration for Wärmedämm-Verbundsystem mit EPS Dämmstoff Geklebt und Gedübelt; IBU: Berlin, Germany, 2017.

58. Henkel. Environmental Product Declaration for ETICS-Ceresit Ceretherm Universal XPS; ITB: Warsaw, Poland, 2016.

59. Henkel. Environmental Product Declaration for ETICS-Ceresit Ceretherm Universal MW; ITB: Warsaw, Poland, 2016.

60. Henkel. Environmental Product Declaration for ETICS-Ceresit Ceretherm Universal EPS; ITB: Warsaw, Poland, 2016.

61. Atlas. Environmental Product Declaration for Atlas ETICS External Thermal Insulation Composite System with Expanded Polystyrene Boards (EPS); ITB: Warsaw, Poland, 2019.

62. Atlas. Environmental Product Declaration for Atlas ETICS External Thermal Insulation Composite System with Mineral Wool Boards (MW); ITB: Warsaw, Poland, 2019.

63. Baumit. Environmental Product Declaration for Baumit Pro External Thermal Insulation Composite System (ETICS); ITB: Warsaw, Poland, 2021.

64. Michałowski, B.; Marcinek, M.; Tomaszewska, J.; Czernik, S.; Piasecki, M.; Geryło, R. Michalak, J. Influence of rendering type on the environmental characteristics of expanded polystyrene-based external thermal insulation composite system. Buildings 2020, 10, 47. [CrossRef]

65. Jubizol. Environmental Product Declaration for Toplotno Izolacijski Fasadni System Jubizol EPS in Jubizol MW; ZAG: Ljubljana, Slovenia, 2019.

66. Michalak, J.; Czernik, S.; Marcinek, M.; Michałowski, B. Environmental burdens of external thermal insulation systems. expanded polystyrene vs. mineral wool: Case study from Poland. Sustainability 2020, 12, 4532. [CrossRef] 
67. Potrč, T.; Rebec, K.M.; Knez, F.; Kunič, R.; Legat, A. Environmental footprint of external thermal insulation composite systems with different insulation types. Energy Procedia 2016, 96, 312-322. [CrossRef]

68. Kunič, R. Carbon footprint of thermal insulation materials in building envelopes. Energy Effic. 2017, 10, 1511-1528. [CrossRef]

69. Wall, S. Ewolucja europejskich zasad wprowadzania do obrotu wyrobów budowlanych a wymaganie podstawowe dotyczace wykorzystania zasobów naturalnych. In Proceedings of the 7th International ETICS Conference, Ożarów Mazowiecki, Poland, 9-10 September 2021; Stowarzyszenie na Rzecz Systemów Ociepleń (SSO): Warsaw, Poland, 2021.

70. Michałowski, B.; Michalak, J. Sustainability-oriented assessment of external thermal insulation composite systems: A case study from Poland. Cogent Eng. 2021, 8, 1943152. [CrossRef]

71. Łukasik, M.; Michałowski, B.; Michalak, J. Assessment of the Constancy of Performance of Cementitious Adhesives for Ceramic Tiles: Analysis of the Test Results Commissioned by Polish Market Surveillance Authorities. Appl. Sci. 2020, 10, 6561. [CrossRef]

72. Kulesza, M.; Łukasik, M.; Michalowski, B.; Michalak, J. Risk related to the assessment and verification of the constancy of performance of construction products. Analysis of the results of the tests of cementitious adhesives for ceramic tiles commissioned by Polish construction supervision authorities in 2016-2020. Cem. Wapno Beton 2020, 25, 444-456.

73. Božiček, D.; Kunič, R.; Košir, M. Interpreting environmental impacts in building design: Application of a comparative assertion method in the context of the EPD scheme for building products. J. Clean. Prod. 2021, 279, 123399. [CrossRef]

74. Rasmussen, F.N.; Andersen, C.E.; Wittchen, A.; Hansen, R.N.; Birgisdóttir, H. Environmental Product Declarations of Structural Wood: A Review of Impacts and Potential Pitfalls for Practice. Buildings 2021, 11, 362. [CrossRef]

75. Saint-Gobain Weber. Environmental Product Declaration for System Weber. Therm Natura; Sustainable Construction Platform Centro Habitat: Aveiro, Portugal, 2016.

76. Michalak, J.; Michałowski, B. Understanding of Construction Product Assessment Issues and Sustainability among Investors, Architects, Contractors, and Sellers of Construction Products in Poland. Energies 2021, 14, 1941. [CrossRef]

77. Blum, N.U.; Haupt, M.; Bening, C.R. Why "Circular" doesn't always mean "Sustainable". Resour. Conserv. Recycl. 2020, 162, 105042. [CrossRef]

78. Kienzlen, V.; Erhorn, H.; Krapmeier, H.; Lutzkendorf, T.; Werner, J.; Wagner, A. The Significance of Thermal Insulation Arguments Aimed at Overcoming Misunderstandings, 3rd ed.; Fraunhofer-Publica: Karlsruhe, Germany, 2014; p. 35.

79. Parracha, J.L.; Borsoi, G.; Flores-Colen, I.; Veiga, R.; Nunes, L.; Dionísio, A.; Glória Gomes, M. Faria, P. Performance parameters of ETICS: Correlating water resistance, bio-susceptibility and surface properties. Constr. Build. Mater. 2021, 272, 121956. [CrossRef]

80. Regulation (EC). No. 765/2008 of the European Parliament and the Council. Available online: https://eur-lex.europa.eu/legalcontent/EN/TXT/?uri=celex\%3A32008R0765 (accessed on 20 August 2021).

81. Wittmayer, J.M.; Schäpke, N. Action, research and participation: Roles of researchers in sustainability transitions. Sustain. Sci. 2014, 9, 483-496. [CrossRef]

82. Grazieschi, G.; Asdrubali, F.; Thomas, G. Embodied energy and carbon of building insulating materials: A critical review. Clean. Environ. Syst. 2021, 2, 100032. [CrossRef]

83. Pargana, N.; Pinheiro, M.D.; Silvestre, J.D.; de Brito, J. Comparative environmental life cycle assessment of thermal insulation materials of buildings. Energy Build. 2014, 82, 466-481. [CrossRef]

84. Silvestre, J.D.; Pargana, N.; de Brito, J.; Pinheiro, M.D.; Durão, V. Insulation cork boards—Environmental life cycle assessment of an organic construction material. Materials 2016, 9, 394. [CrossRef] [PubMed]

85. Dovjak, M.; Košir, M.; Pajek, L.; Iglič, N.; Božiček, D.; Kunič, R. Environmental impact of thermal insulations: How do natural insulation products differ from synthetic ones? IOP Conf. Ser. Earth Environ. Sci. 2017, 92, 012009. [CrossRef]

86. Kraus, M.; Žáková, K.; Žák, J. Economic-environmental and technological assessment of ETICS. EasyChair 2020, 3425.

87. Žák, J. Positive and Negative Aspects of ETICS. MATEC Web Conf. 2019, 279, 03011. [CrossRef]

88. Rezai, S.H.; Allard, F.; Abelé, C.; Doya, M. Evaluating external thermal insulation composite systems (ETICS) regarding the building's global performance. Energy Procedia 2015, 78, 1562-1567. [CrossRef]

89. Streimikiene, D.; Skulskis, V.; Balezentis, T.; Agnusdei, G.P. Uncertain multi-criteria sustainability assessment of green building insulation materials. Energy Build. 2020, 219, 110021. [CrossRef]

90. Tůmová, E.; Drochytka, R.; Černý, V.; Čada, P. Development of organic and biodegradable insulating material for ETICS. Procedia Eng. 2017, 195, 81-87. [CrossRef]

91. Librelotto, L.I.; Kekez, M.; Bártolo, H.M.G. The environmental impact of an ETICS layer: A case of study with Life Cycle Assessment (LCA) from Environmental Product Declaration (EPD) in Portugal. MIX Sustentável 2020, 6, 139-148. [CrossRef]

92. Czernik, S.; Marcinek, M.; Michałowski, B.; Piasecki, M.; Tomaszewska, J.; Michalak, J. Environmental Footprint of Cementitious Adhesives-Components of ETICS. Sustainability 2020, 12, 8998. [CrossRef]

93. Malanho, S.; Veiga, R.; Farinha, C.B. Global Performance of Sustainable Thermal Insulating Systems with Cork for Building Facades. Buildings 2021, 11, 83. [CrossRef]

94. Matos, M.; Soares, L.; Silva, L.; Sequeira, P.; Carvalho, J. Life cycle assessment of an ETICS system composed of a natural insulation material: A case study of a system using an insulation cork board (ICB). In Portugal SB13 Contribution of Sustainable Building to Meet EU 20-20-20 Targets; Multicomp-Artes Gráficas: Lda Guimarães, Portugal, 2013; Chapter 11; pp. 855-862. Available online: https:/ / www.irbnet.de/daten/iconda/CIB_DC26483.pdf (accessed on 26 August 2021).

95. Silvestre, J.D.; Castelo, A.M.; Silva, J.J.; de Brito, J.M.; Pinheiro, M.D. Retrofitting a building's envelope: Sustainability performance of ETICS with ICB or EPS. Appl. Sci. 2019, 9, 1285. [CrossRef] 
96. Minarovičová, K. Environmental aspect of maintenance of buildings with ETICS. MATEC Web Conf. 2019, 279, 03005. [CrossRef]

97. Minarovičová, K.; Dlhý, D. Environmentally safe system for treatment of bio corrosion of ETICS. MATEC Web Conf. 2018, 146, 3005. [CrossRef]

98. Minarovičová, K.; Antošová, N. Sustainability of ETICS maintenance technologies. Appl. Mech. Mater. 2016, 820, 194-199. [CrossRef]

99. Ströbele, B.; Lützkendorf, T. Communicating environmental information: Rethinking options for construction products. Build. Res. Inf. 2019, 47, 681-696. [CrossRef]

100. Papadopoulou, P.; Peñaloza, D.; Asbjörnsson, G.; Hulthén, E.; Evertsson, M. Development of a Pre-Verified EPD Tool with Process Simulation Capabilities for the Aggregates Industry. Sustainability 2021, 13, 9492. [CrossRef] 